\title{
Na casa e... na rua: cartografias das mulheres na cidade (Campina Grande, 1930-1945)*
}

\author{
Fabio Gutemberg Ramos Bezerra de Sousa**
}

\begin{abstract}
Resumo
Neste artigo fazemos uma incursão específica no mundo das mulheres. O locus do estudo é a cidade de Campina Grande, Paraíba, nos anos de 1930 a 1945, tendo como objeto os significados e implicações que algumas atividades das mulheres do meio popular tinham para a cidade e o modo como utilizavam seus espaços e territórios. Também buscamos reconstituir aspectos cotidianos da trajetória de algumas mulheres pelas ruas e subúrbios da cidade, focalizando características singulares de mulheres anônimas que apareceram na cena urbana, fazendo da cidade um lugar de múltiplas práticas, relações e conflitos.
\end{abstract}

Palavras-chaves: Mulheres, Gênero, Cidade, Cotidiano popular.

\footnotetext{
" O artigo é parte do segundo capítulo da tese de doutorado do autor, Cartografias e imagens da cidade: Campina Grande (1920-1945). Doutorado em História, Campinas, Unicamp, 2001. Recebido para publicação em agosto de 2004, aprovado em janeiro de 2005.

** UFCG, Campinas Grande, PB, Brasil. fgrbsousa@hotmail.com

cadernos pagu (24), janeiro-junho de 2005, pp.153-174.
} 
Na casa e... na rua

At Home and... On the Streets: Cartography of Women

Around the City (Campina Grande, 1930-1945)

\begin{abstract}
This article brings a specific gaze into women's world. The locus of our study is the city of Campina Grande (Paraiba) from 1930 to 1945, emphasising the meanings and implications of some activities carried out by working class women through the city, and the ways they used its spaces and territories. We also seek to rebuild everyday aspects of their trajectories through streets and suburbs, focusing singular characteristics of anonymous women who appeared at the urban scene turning it into a place of multiple practices, relations and conflicts.
\end{abstract}

Key words: Women, Gender, City, Popular Everyday Life. 
Fabio Gutemberg Ramos Bezerra de Sousa

\section{Introdução}

Este artigo propõe uma incursão específica no mundo das mulheres. Não busco analisar movimentos e ações coletivas das mulheres ou episódios marcantes da história brasileira e o papel por elas desempenhado; também não estudo um período de inflexões marcantes nas relações de gênero no Brasil; não me interessa, muito embora não a desconheça, a tutela que a família patriarcal ou o Estado sobre elas exercia; nem também mulheres de trajetórias excepcionais que figuram nos anais do movimento feminista. As personagens das histórias que o leitor vai encontrar neste texto são mulheres anônimas, donas de casas que não deixaram seus nomes nos anais de nenhuma história; mulheres simples que entre muitas outras coisas precisavam lutar cotidianamente pela sobrevivência, mas que apesar das adversidades do dia a dia, silenciosa e sub-repticiamente, ampliaram as possibilidades $e$ as formas de estar no mundo em que viviam.

Procuro compreender o cotidiano de mulheres do meio popular seguindo três recortes: primeiro, o palco das investigações é a cidade, o que me levou a buscar os significados e implicações que suas atividades tinham para a cidade e o modo como utilizavam alguns espaços e territórios; segundo, busco reconstituir aspectos da trajetória e da vida de algumas mulheres no seu cotidiano, privilegiando escalas menores, como suas andanças pelas ruas e subúrbios da cidade e suas relações cotidianas, embora não as isole das mudanças e questões mais gerais por que passava a sociedade e o país; por fim, interessa a aproximação com mulheres que, por motivos vários, apareceram na cena urbana (não estão entre estes motivos manifestações como a participação em passeatas, greves), dando-lhe características singulares que fazem da cidade um lugar de múltiplas práticas, relações e conflitos. ${ }^{1}$

${ }^{1}$ A historiografia que tem como objeto a cidade nomeia e identifica essa 
Na casa e... na rua

\section{O mundo das mulheres $e$ a cidade}

Nos mais diversos lugares da cidade de Campina Grande encontramos, nas décadas de 1930 e 1940, centenas de famílias e vizinhos convivendo harmoniosamente ou vivendo pequenas tensões. Nessas relações, marcadas por práticas de solidariedade $e$ conflitos, as mulheres desempenham um papel crucial, revelando ao leitor facetas das formas como apareciam e usavam certos lugares e territórios da cidade. ${ }^{2}$

Flagramos mulheres em relações com vizinhos, familiares, maridos e amásios; as diversas facetas da sua luta pela sobrevivência, os usos que faziam de certos espaços da casa e da rua e os conflitos em que vez por outra se envolviam. Tudo isso

multiplicidade, mas raramente aprofunda-a na direção dos grupos populares. $\mathrm{Na}$ maioria dos casos opta por acompanhar o discurso de intelectuais e letrados sobre os diversos grupos e classes ou fenômenos como a multidão, disciplina, etc.; ente outros ver BRESCIANI, Stella. Paris e Londres no século XIX: o espetáculo da pobreza. $4^{\text {a }}$ ed., São Paulo, Brasiliense, 1987; PECHMAN, Robert Moses. Um olhar sobre a cidade: estudo da imagem e do imaginário do Rio na formação da modernidade In: Cidade \& História. Salvador, UFBA/Faculdade de Arquitetura. Mestrado em Arquitetura e Urbanismo; ANPUR, 1992, pp.33-44; PONTE, Sebastião Rogério. Fortaleza Belle Époque: reformas urbanas e controle social (1860-1930). Fortaleza, Fundação Demócrito Rocha/Multigraf Ed. Ltda, 1999 e Pesavento, Sandra J. Os Pobres na Cidade. Porto Alegre, Editora UFRGS, 1994. As exceções que conheço são os trabalhos de LANNA, Ana L.D. Uma cidade na transição: Santos - 1870-1913. São Paulo/Santos, Hucitec /Prefeitura Municipal de Santos, 1996; Chalhoub, Sidney. Trabalho, lar e botequim. Rio de Janeiro, Paz e Terra, 1986; ARRAIS, Raimundo. Recife: culturas e confrontos. Natal, Editora da UFRN, 1998; e DIAS, Maria Odila L.S. Quotidiano e poder em São Paulo no século XIX. $2^{\mathrm{a}}$ ed. Revisada. São Paulo, Brasiliense, 1995; RoLNIK, Raquel. A cidade e a lei. Legislação, política urbana e territórios na cidade de São Paulo. São Paulo, Studio Nobel/FAPESP, 1997 e WISSENBACH, Cristina. Da escravidão à liberdade: dimensões de uma privacidade possível In: Sevcenko, Nicolau. (org.) História da vida privada no Brasil. São Paulo, Cia das Letras, 1998, vol. 3. fazem este exercício para ex-escravos e negros.

2 Fichei 289 processos criminais que se encontram no arquivo da $1^{\text {a }}$ Vara do Tribunal do Júri de Campina Grande. Selecionei todos os processos envolvendo crimes de homicídio, tentativa de homicídio, luta corporal e agressão ocorridos no espaço urbano de Campina Grande no período de 1925 a 1945. 
conduz ao cotidiano das donas-de-casa e mulheres do meio popular em Campina Grande. ${ }^{3}$

A maioria dos casos adiante narrados ocorreu entre os subúrbios e adjacências do centro da cidade, o que mostra que desde os primeiros anos da década de 30 eram áreas com forte presença popular.

No ano de 1934, deparamo-nos com um episódio que parecia ser comum no universo das famílias de trabalhadores. Um marido desempregado muda-se com a esposa para passar uns tempos na casa do seu cunhado, mas a presença do novo casal na pequena morada acirrou os problemas do casal anfitrião, o que levou a esposa, inconformada, a deixar sua casa levando alguns utensílios domésticos, tendo passado a viver com uma vizinha, próxima a sua moradia anterior. ${ }^{4}$

Essa rápida história coloca diante do leitor indícios das relações cotidianas entre as camadas populares. Um dos seus começos parece ser a precária situação em que se encontravam José Batutinha e Moça Chaves, vítimas do desemprego. A saída para eles fora passar uns tempos na casa do irmão de Moça Chaves, um cozinheiro que parecia estar em melhor situação. Era uma estratégia de sobrevivência comum entre familiares que moravam na cidade, quando passavam por dificuldades. Costumavam se desfazer da casa em que moravam quase sempre alugada e, com o apoio logístico de familiares e parentes, tinham uma moradia até o homem encontrar um trabalho. Raramente era a mulher quem o fazia, muito embora algumas tentassem quebrar esse costume, correndo riscos e alargando possibilidades.

Em um episódio ocorrido cerca de onze anos depois, em 1945, vê-se um exemplo da última assertiva. A doméstica Petronila Vieira, além de fumar cachimbo, engomava roupa, o que muito

\footnotetext{
${ }^{3}$ Considero apenas as mulheres do meio popular que aparecem nos processos como domésticas.

4 Ação Criminal n 53, 1934, José Severino Pereira, José Batista Chaves e Luiza Pereira Chaves, maço de 07/06 a 25/10/1934.
} 
Na casa e... na rua

incomodava o marido, que acabou espancando-a. O interessante na atitude da espancada e reincidente Petronila é que continua reincidindo e não se faz de rogada ao dizer que assim age de "há muito". Afirma ainda, como que em deboche, "que continua a fumar por ser um vício não muito feio, muito embora prejudicial". O seu discurso é um forte apelo no sentido de ver a renda familiar complementada. $\mathrm{O}$ trabalho como engomadeira era realizado com vista a complementar a renda do marido, que devia ser parca e, especialmente, para comprar "vestimentas para si e para suas filhas". ${ }^{5}$

A história da busca da mulher casada por um trabalho remunerado era sinuosa. Não fica claro na documentação pesquisada, mas algumas mudanças nessas práticas e relações podem ter ocorrido no período que este trabalho abrange. Os únicos indícios que tenho dizem respeito às mulheres de elite, $e$ não é bom generalizá-los. ${ }^{6}$ Caso tenham ocorrido, interferiram na

5 Ação Penal n 278, 1945, Antônio Vieira da Silva, maço de 15/01 a 28/04/1945. Essa atitude de Petronila não devia ser uma exceção entre aquelas mulheres, apesar dos conflitos que podiam gerar com os seus maridos e amásios. Ver Ação Criminal n 70, 1935, Antônio Alves de Oliveira, maço de 28/02 a 16/12/1935, em que mulher deixa o amásio e passa a viver de costura, não aceitando a feira que o mesmo a mandou, o que fez com que ex-amásio a agredisse.

${ }^{6}$ Para uma discussão sobre o trabalho da mulher e, de forma mais ampla, sobre a construção dos códigos de sexualidade feminina em algumas regiões do Brasil entre o final do século XIX e primeiras décadas do XX, ver RAGO, Margareth. Os prazeres da noite. Rio de Janeiro, Paz e Terra, 1991; MALUF, Marina e MOTT, Maria Lúcia. Recônditos do mundo feminino. In: História da vida privada no Brasil. República: da Belle Époque a era do rádio. São Paulo, Companhia das Letras, 1998, pp.367-422, vol. 3; EsTEVES, Martha Abreu. Meninas perdidas. Rio de Janeiro, Paz e Terra, 1989 e CAULFIELD, Suenn. Em nome da honra. Moralidade, modernidade e nação no Rio de Janeiro (1918-1940). CampinasSP, Editora da Unicamp/Centro de Pesquisa em História Social da Cultura, 2000; para Campina Grande e João Pessoa no período de 1920-1950, ver CAVALCANTI, Silêde Leila O. Mulheres modernas, mulheres tuteladas: o discurso jurídico e a moralização dos costumes em Campina Grande (1930-1950). Mestrado em História, Recife, UFPE, 2000 e ABRANTES, Alômia. As escritas femininas e os 
redefinição dos espaços físicos e simbólicos e nas relações de poder e gênero na cidade, especialmente porque deslocavam as mulheres dos afazeres domésticos para lugares outros que não a casa e o seu entorno, possibilitando mudanças em um dos pilares das relações entre casais, que reservava ao homem o trabalho fora de casa e à mulher as atividades domésticas.

Em um caso de 1944, pequenos indícios mostram o quanto a vida daquelas mulheres $e$ homens era cheia de problemas, levando-os a malabarismos diversos para continuarem no mundo. ${ }^{7}$ Mais uma vez, o trabalho desencadeara a questão. Noé Ferreira da Silva que havia se ausentado de Campina em busca de emprego, passou uns tempos entre João Pessoa e uma cidade do interior de Pernambuco. Segundo Severina Marques, "a princípio o seu marido mandava para ela e seu filho, algumas coisas, mas depois deixou de mandar"; o que o marido nega, informando que "sempre lhe mandava dinheiro para a feira, ou mesmo vinha trazer". No entanto, desde que Noé partira, Severina Marques e o filho ficaram na casa de uma vizinha, após serem despejados, e desta última só saíram quando Noé voltou e agrediu sua esposa.

Num pequeno lapso de tempo, deparam-se mulher e filho em três situações diferentes: por inadimplência, foram despejados da casa alugada em que viviam, mas uma vizinha grávida deulhes guarida em troca de ajuda no pós-parto; por fim, acabaram indo para a casa de familiares. Nesse momento, perde-se o contato com Severina Marques, mas pode-se observar que entre aquelas pessoas havia uma extensa e complexa rede de solidariedade a acolher mulheres que em certos momentos viviam as agruras do despejo pelo senhorio ou do abandono pelo marido. Essas práticas são encontradas em todo o período

femininos inscritos. Imagens de mulheres na imprensa Parahybana dos anos 20 . Mestrado em História, Recife, UFPe, 2000.

7 Cf. Ação Penal n² 232, 1944, Noé Ferreira da Silva, maço de 13/04 a 31/08/1944. 
Na casa e... na rua

estudado e apareciam de formas diversas, mas eram recorrentes. Apoio logístico após abandono do marido ou amásio; extensa rede de parentes e familiares a dar guarida em momentos difíceis; vizinhos e vizinhas ajudando na alimentação ou no cuidado dos filhos quando a mulher, viúva, abandonada ou mãe solteira precisava trabalhar fora de casa; agricultores trazendo ajuda in natura para compadres e comadres que moravam na cidade, etc.

A outra face dessa rede de solidariedade entre pobres $e$ mulheres abandonadas era constituída pelos conflitos que essas aproximações proporcionavam. Conflitos entre parentes $e$ familiares ou vizinhos eram comuns quando mais de uma família ocupava uma casa, ${ }^{8}$ mas não ocorriam apenas nestas situações. Era uma prática corriqueira, especialmente entre mulheres jovens e recém-casadas, irem morar próximo aos familiares. Parecia ser uma estratégia de sobrevivência entre grupos e famílias pobres, mas não era somente isso, pois, ao mesmo tempo em que os pais ajudavam na manutenção do novo casal em dificuldades, as mães mais experientes aproveitavam para acompanhar a relação da filha com o marido e ajudá-la também emocionalmente. Essa proximidade será de grande serventia em períodos de dificuldades, mas em certas circunstâncias desembocará em conflitos.

Um caso de 1940 coloca outras tantas questões além das mencionadas anteriormente. Clotilde Machado havia se casado com o vigia da Great Western Francisco Machado, paradoxalmente, contra a vontade e sob a pressão de sua mãe, Severina Gonçalves. ${ }^{9}$ A operária e viúva Severina Gonçalves, 35 anos, sempre fora contra o namoro de Clotilde com Francisco, o que o levou a raptá-la e deflorá-la. Severina Gonçalves foi então à polícia para obrigá-lo a casar-se com sua filha. Isso criou uma

${ }^{8}$ Cf. Chalmoub, S. Trabalho, lar e ... Op. cit., pp.88-101.

9 Ação Criminal n 160, 1940, Severina Gonçalves de Sousa e Clotilde Machado, Maço de 02/01 a 13/06/1940, acusadas de tentarem matar Francisco Machado, marido de Clotilde. 
celeuma entre sogra e genro, que ficaram intrigados. Mesmo assim, Severina aceitara o casal morando em sua casa. Moraram juntos dois meses, mas como Francisco batia em Clotilde na sua ausência, Severina "aconselhara sua filha a induzir a este [Francisco] para alugar uma casa e se retirarem da sua", o que terminou ocorrendo. Porém, Francisco, além de continuar batendo em Clotilde, proibira a mãe de visitá-la.

Não foi o único marido a tentar cortar as relações entre pais que interferiam nas relações de suas filhas casadas, especialmente quando moravam próximos, embora essa não fosse condição única ou básica para essa interferência. ${ }^{10} \mathrm{Em}$ um episódio de 1934, Júlia Francisca Xavier fora espancada pelo marido Sebastião Pereira Ramos após voltar de uma visita que fizera à casa dos pais na mesma rua em que morava. ${ }^{11}$ Segundo informou, os ciúmes do marido chegaram ao cúmulo de não consentir, "sequer, que a declarante visite os seus pais". Ao agir assim, Sebastião mostrava perceber que aquelas visitas terminavam sendo uma ameaça para a continuidade do seu casamento, marcado por discórdias e pelos seus ciúmes. Júlia, vez por outra, dizia "não querer mais fazer vida" com o ciumento marido, que vivia a espancá-la. A família dela devia ser sua principal aliada nessa ameaça e Sebastião sabia disso. Isolá-los do convívio com a mulher parecia ser a saída. O mesmo havia pensado Francisco Machado ao proibir Clotilde de visitar a mãe.

$\mathrm{O}$ episódio envolvendo Severina Gonçalves, Clotilde e Francisco, no entanto, mostra muito mais do que as práticas de solidariedade e conflitos entre familiares e casais que moravam sob o mesmo teto. Nele flagra-se a jovem viúva Severina Gonçalves trabalhando como operária para manter-se com duas filhas numa sociedade em que havia fortes restrições ao trabalho

\footnotetext{
${ }^{10}$ A própria Severina ficara morando em lugar relativamente distante de Clotilde e Francisco após estes deixarem sua casa.

${ }^{11}$ Ação Criminal $n^{\circ}$ 62, 1934, Sebastião Pereira Ramos, Maço de 31/07 a $17 / 11 / 1934$
} 
Na casa e... na rua

da mulher fora de casa, tal como se viu na reação de Antônio Vieira às tentativas de Petronila. Mas este era um caso diferente, pois se tratava de um casal e, mesmo precariamente, dele fazia parte um marido cioso de suas responsabilidades. Severina, diferentemente, não dispunha mais do apoio do marido, tendo que procurar, sozinha, meios de sobreviver com as duas filhas, quando aconteceu o fatídico episódio do rapto, defloramento e casamento de Clotilde. Ao mesmo tempo, flagra-se mais uma vez um casal "pobre" morando de aluguel e com minguados recursos para sobreviver, a acreditar na quantia que Francisco deixara para Clotilde passar dois dias e que ainda deveria ser suficiente para recepcioná-lo com a janta, quando da sua volta de João Pessoa. Sabendo da situação precária em que sua filha ficara, Severina Gonçalves pediu à filha mais nova para ir à casa de Clotilde chamá-la para passar com ela os dias em que o marido ficasse fora.

Pode-se retomar novamente o caso de José Cozinheiro e Ana Pereira e adentrar outros meandros daquelas relações. Ana, ao deixar a casa em que vivia com o marido, levara consigo quase toda a mobília e lançara mão também de três galinhas. José Cozinheiro informou que as galinhas eram alheias, mas não diz exatamente de quem eram. Talvez pertencessem ao hotel em que trabalhava como cozinheiro. De um ou de outros as galinhas pareciam ter algum significado para aquelas pessoas; por isso José lembrara delas, denunciando os excessos de Ana Pereira.

Em 1932, dois anos antes do caso que envolvera Ana e José Cozinheiro, entre risadas e interrogações descobre-se como as galinhas eram parte do mundo daquelas pessoas. ${ }^{12}$ É uma história nebulosa e hilária ao mesmo tempo. Pretensa dona de uma galinha que acabara de ter três pintos, Josefa Henrique da Silva percebeu o quão difícil seria cuidar daquela família e dar conta de outros afazeres domésticos. Por isto resolveu abdicar de parte

${ }^{12}$ Ação Criminal $n^{\circ}$ 20, 1932, Francisca Alves de Oliveira e Josefa Henrique Dias, maço de 24/02 a 23/11/1932. 
dela, lançando mão de uma prática costumeira: pediu a uma vizinha para criar a dita galinha e, em troca, doava-lhe os três pintinhos. ${ }^{13}$ A "negra" Flauzina não teve dúvidas e aceitou o negócio, conduzindo a família de ovíparos para casa. Mas tinha também diversos outros afazeres, descuidou-se e lá se foi a galinha e a prole mundo afora. Quando deu conta do desaparecimento, Flauzina saiu desesperada pela vizinhança perguntando pela galinha e foi encontrá-la, amarrada à corda, na casa de Francisca Alves de Oliveira. Francisca disse que a galinha lhe pertencia $e$ havia desaparecido de sua casa há cerca de 45 dias. Achava que a galinha tinha sido roubada e ficou feliz em tê-la recuperado, ainda mais agora, com a sua multiplicação. Utilizava-se de dois argumentos envolventes para provar seus direitos sobre a galinha: informava que era "uma galinha amarela" e, quando de sua casa escafedera-se, estava em fase de "postura", o que explicava a sua volta 45 dias depois acompanhada da prole.

Flauzina achou estranha aquela história e correu à casa de Josefa Henrique. Josefa, ao saber da novidade, imediatamente tomou o rumo da casa de Francisca Alves e, lá chegando, não se fez de rogada: "logo foi arrebatando a galinha". Josefa assim narra o episódio:

entrou para a casa de Francisca Alves e quando entrou foi vendo a dita franga [sic], que estava ali, e disse a Francisca Alves que aquela franga lhe pertencia, a que Francisca disse que não, e logo ela, sem demora, pegou a franga para conduzi-la e nessa ocasião, Francisca e suas filhas pegaramse com ela interrogada e uma delas gritou, "traz os cacetes",

\footnotetext{
${ }^{13}$ Essas práticas, denominadas de "meia", são comuns, especialmente na zona rural de certas áreas do Nordeste, e muitas vezes alcançam as próprias cidades e se perpetuam entre populares, muito embora na cidade assumam uma nova dimensão por causa de questões como a falta de espaço e de tempo para cuidar dos animais.
} 
Na casa e... na rua

desencadeando uma luta corporal entre as contendoras, que terminou com ambas feridas. Após a refrega, saíram para a delegacia de polícia.

As testemunhas, todas vizinhas, fazem coro com as contendoras e insistem em colocar a galinha como o centro da querela. Elas realmente tinham significado para aquelas pessoas $e$ o conflito é um emblema de como aquele mundo tinha sua própria lógica. Mas era uma lógica que não condizia com certos preceitos pregados por médicos e higienistas da época, que vinham tentando limitar a geografia dos populares e os lugares onde deviam criar seus animais domésticos. ${ }^{14}$ No caso envolvendo Josefa Henrique, Francisca Alves, Flauzina e outras vizinhas, observam-se práticas comuns no campo tomando as ruas dos subúrbios da cidade e as imediações do centro. Galinhas, cachorros e porcos soltos pelas proximidades da casa em área urbana era sinal de que aquelas pessoas tinham uma percepção diversa do espaço em torno da casa, utilizando-o com uma liberalidade que os preceitos da higiene burguesa não comportavam. ${ }^{15}$

Aqueles animais serviam para aproximar pessoas e criar laços de solidariedade com vizinhos, o que ampliava os espaços das pequenas moradias, tal como se viu na relação entre Flauzina e Josefa Henrique. A mistura de galinhas, porcos, animais diversos e pessoas nas casas e nas ruas, o uso comum de determinados espaços ditos privados, os diversos tipos de trocas não monetárias, que faziam parte do cotidiano dos pobres e trabalhadores, eram condenados pelo discurso higienista e burguês como sinônimo de

${ }^{14}$ O Código de Posturas de Campina Grande de 1927 é o mais claro sinal nesta direção. Ver também PIMENTEL, Cristino. Abrindo o livro do passado. Campina Grande, Editora Teone, 1956, pp.181-185, em memória intitulada "Rua Monsenhor Sales" em que relembra peripécias de Zé Bernardino, proprietário de um hotel que permitia a convivência de comensais com galinhas, porcos e cavalos.

${ }^{15}$ Cf. WissenBACH, C. Da escravidão à liberdade... Op. cit., p.121 e LANNA, A. Uma cidade na..., Op. cit., p.87 e 119. 
promiscuidade e um risco para a saúde e a moral da sociedade, porque embaralhavam e embotavam códigos que se tentava universalizar e punham em cheque alguns pilares da sociedade moderna, como a família nuclear, a monetarização das relações sociais $e$ a separação entre espaço público e privado. ${ }^{16}$ Condenando os animais criados soltos nas ruas à exígua geografia do chiqueiro ou do estábulo asséptico, buscava-se mais do que garantir a saúde dos moradores e prevenir epidemias nas cidades, pois abria um sutil caminho, ou uma larga avenida, para interferir nos territórios populares, desestruturando os laços de solidariedade e ajuda mútua que ali dominavam. ${ }^{17}$

Além do papel que esses animais tinham na vida de famílias populares, outros aspectos chamam a atenção nos casos anteriormente narrados: as relações de solidariedade, os conflitos entre vizinhas e os usos que as mulheres faziam da casa e do seu entorno.

Retornarei mais uma vez ao caso de Ana Pereira e José Cozinheiro. Ana, após desentendimentos com seu marido, fora em demanda de uma vizinha e não de familiares, provavelmente por não tê-los na cidade. Além do apoio logístico, a sua vizinha e agora anfitriã Luzia Maria da Silva fora testemunha da agressão; em sua casa Ana se refugiara quando sua cunhada, Moça Chaves, perseguiu-a de enxada na mão, soltando impropérios $e$ ameaçando-a. Luzia não só serviu de testemunha de acusação como mobilizou o marido, que no momento da agressão estava ausente, e deu ao mesmo instruções para depor em favor de Ana.

${ }^{16}$ Cf. WissEnBACH, C. Da escravidão à liberdade... Op. cit., pp.49-130.

${ }^{17}$ As obras de Rolnik, Arrais, Chalhoub e Wissenbach discutem a dimensão política das tentativas das elites e classes dominantes de interferir e desarticular territórios populares e negros em diferentes cidades brasileiras. ROLNIK, R. $A$ cidade e... Op.cit., ARRAIS, R. Recife: culturas e... Op. cit., ChalHouB, S. Trabalho, lar e... Op. cit., Visóes da liberdade: uma história das últimas décadas da escravidão na corte. São Paulo, Companhia das Letras, 1990 e Cidade febril. Cortiços e epidemias na Corte imperial. São Paulo, Companhia das Letras, 1996 e WiSSENBACH, C. Da escravidão à liberdade... Op. cit., pp.49-130. 
Na casa e... na rua

Em grande parte dos processos criminais pesquisados, percebe-se o quanto a relação entre vizinhos era importante naquele mundo. ${ }^{18}$ Por um lado, ela criava laços de solidariedade que desembocavam em atitudes como as que se viu no parágrafo anterior. Mas exercia encantos mil e provocavam outras tantas desavenças. Não ocorria somente entre mulheres, como até aqui se viu, mas elas eram seus principais esteios. Quando casadas ou amasiadas, e o marido tinha um trabalho ou emprego, eram responsáveis pelos afazeres domésticos. É claro que nem todas se dedicavam exclusivamente aos serviços do lar, como imaginavam e queriam os seus maridos e uma certa moral, mas grande parte de suas atividades e da sua vida tinha como referência espacial a casa. Desta entabulavam conversações e criavam laços de cumplicidade com a vizinhança.

Aquele mundo era propício a essas aproximações. Casas pequenas, na maioria parede-meia, onde se ouvia tudo que ocorria na casa vizinha. ${ }^{19}$ Ao fundo da casa ficava a cozinha $e$ após essa o quintal, onde parte dos afazeres domésticos era realizada $e$ onde as mulheres conversavam, para dar vazão às agruras da labuta diária. Os quintais eram, na maioria das vezes, separados por uma cerca de varas, o que era uma forma de limitar as andanças dos animais domésticos na cidade. Em frente da casa havia o terreiro ou a calçada, local que deveria passar por uma limpeza diária e que era usado pelas mulheres para colocar as conversas em dia e saber das novidades da vizinhança e da cidade. Entabulavam-se conversas e criavam-se laços; confidenciavam sobre suas relações, seus problemas e alegrias,

\footnotetext{
${ }^{18}$ Ver também ChalHoub, S. Trabalho, lar e... Op. cit.

${ }^{19} \mathrm{Em}$ alguns processos os vizinhos informam que tomaram conhecimento do acontecido porque moravam parede-meia com a casa onde ocorrera o crime. Uns confessam, inclusive, que ouviam tudo que se conversava na casa vizinha. Ver Ação Criminal n 70, 1935, Antônio Alves de Oliveira, maço de 28/02 a 16/12/1935, Ação Criminal n 78, 1934, Ananias Severino, maço de 13/01 a 06/07/1935 e Ação Criminal n 93, 1936, Antônio Maximiano Carneiro, maço de 21/01 a 30/12/1936.
} 
projetos futuros e desencantos com o mundo. Marido, filhos, família, vizinhos, tudo era mote para prolongar aquelas conversas. Ali também faziam articulações contra as possíveis agressões de maridos ciumentos; discutiam a educação e cuidado dos filhos, ou como evitar a sua concepção; conversavam sobre o amor e o amar; ensinavam umas às outras os caminhos que levavam à delegacia, caso sofressem alguma agressão por parte do amásio, ou de vizinhos e desafetos, e davam combustível para alimentar aquelas formas de estar num mundo cheio de adversidades.

A casa e o seu entorno, as casas vizinhas, os quintais, a rua, o roçado, muitas vezes próximo, compunham um espaço amplo, mesmo que a casa em si não o fosse na maioria das vezes. Era um amplo espaço por ser lugar de muitas articulações, onde se podiam fazer muitas coisas. O ciumento Sebastião Pereira Ramos acusou Júlia de viver em sua casa "a se enamorar com uns homens que passavam na rua". ${ }^{20}$ Sebastião era lavrador e é difícil imaginar que alguma vez tenha flagrado Júlia em seus flertes. Provavelmente soube das façanhas da mulher através de um vizinho ou parente indignado. Noé Ferreira, quando voltou a casa em que agredira sua mulher dias antes, encontrou uma vizinha "escanchada" na porta da frente a conversar com Severina $e$ Maria Bezerra, a proprietária da casa. ${ }^{21}$ Irritado com o que deve ter considerado uma licenciosidade, chamou a mulher que estava na porta de "catraia". Em outro caso, Crispiniano Norberto e Maria Rosa da Conceição haviam se pegado pela manhã, por causa de ciúmes, e Maria deixou a casa em que vivia com o amásio, indo para a casa de uma vizinha e amiga. ${ }^{22} \mathrm{Na}$ noite daquele mesmo dia, estava debruçada em uma janela, conversando com um homem, quando Crispiniano chegou $e$ a agrediu.

\footnotetext{
${ }^{20}$ Ação Criminal n 62.

${ }^{21}$ Ação Penal n 232.

${ }^{22}$ Ação Criminal n 16, 1932, Crispiniano Norberto e Maria Rosa da Conceição, maço 02/02 a 14/12/1932.
} 
Na casa e... na rua

Esses são exemplos dos usos que faziam de uma casa. Quintal e calçada ou terreiro, cozinha, sala da frente, portas e janelas. Tudo aquilo podia ser muito diminuto, mas servia para movimentos bem mais amplos do que seu espaço físico fazia crer. Crispiniano, Noé e Sebastião descobriram que as janelas ou portas de suas moradias tinham sentidos diversos e eram mais do que a entrada ou serventia da casa; eram lugares de onde se podia entabular diálogos com a rua, com vizinhos, com transeuntes, com negociantes; era, enfim, em certos aspectos, uma movimentada banca de trocas material e simbólica.

Em um episódio de 1932 percebe-se o quanto algumas daquelas mulheres eram desabusadas. Severino Ramos, vulgo Severino Baleado, ao chegar em casa no Louseiro, subúrbio de Campina Grande, vindo de andanças na rua às duas horas da madrugada, encontrou Antônia Maria da Conceição, sua mulher, atracada e aos beijos com Antônio Eufrásio. Espancou-a e esta se socorreu na casa de um vizinho. ${ }^{23} \mathrm{Em}$ seu depoimento na delegacia, Severino informou que ia

chegando em sua casa vindo da rua e ao aproximar-se, encontrou sua mulher com a porta aberta e agarrada com Antônio Eufrásio; que neste ínterim Antônio Eufrásio correu, e sua esposa correu também, saindo, tendo ele a alcançado no terreiro

quando a espancou pela primeira vez. Antônia em sua versão, informa que após interrogação do irado Severino, confessou ao marido que tudo não passara de um beijo. Assim ela narra o momento que antecedeu ao episódio:

...às duas horas da madrugada, estava em sua casa, quando ouviu uns assovios (sic) e tropéis em direção de sua casa; que ela chamou pelo nome do seu marido que andava fora, pensando ela ser seu marido, que se destinava

${ }^{23}$ Sumário Crime n 25, 1932, Severino Ramos, maço de 16/06 a 19/10/1932. 
Fabio Gutemberg Ramos Bezerra de Sousa

a casa; que após haver chamado pelo nome do seu marido, respondeu um seu vizinho de nome Antônio Eufrásio, dizendo "sou eu dona Antônia"; que lhe pedia uns fósforos; que ela depoente satisfez o pedido deste..$^{24}$

Eufrásio parece ter pedido algo mais do que fósforos naquela madrugada e "dona Antônia" atendeu aos seus apelos, porque os lances seguintes foram presenciados por Severino Baleado, que a submeteu a duas sessões de espancamento. Antônia inovou e subverteu os usos que as mulheres casadas faziam até então da porta e janela de uma casa. Nos processos pesquisados, as portas das casas eram usadas na maioria das vezes para conversas com vizinhas $e$ amigas, que se visitavam quase sempre à noite. ${ }^{25}$

A ousadia de Antônia mais uma vez surpreende. É certo que utilizou um horário morto para ficar aos beijos e agarradelas com Eufrásio na porta de sua casa; mesmo assim, demonstrou ser uma mulher de coragem. Confirmou esta condição ao confessar ao marido revoltado que apenas "beijara Eufrásio". No seu depoimento, percebem-se as artimanhas e uma certa cumplicidade com o amante, pois se comunicavam através de assobios quando queriam se encontrar a sós. Mas se o horário e os assobios eram as formas de Eufrásio e Antônia se comunicar e burlar a vigilância dos vizinhos e do marido, muitos outros vizinhos e vizinhas se comunicavam diversamente e, muitas vezes, sem a "discrição" de Antônia e Eufrásio. ${ }^{26}$

\footnotetext{
${ }^{24}$ ID.

${ }^{25}$ Em um processo de 1944, flagra-se outro uso da porta/janela de uma casa, só que no caso, por um homem. Segundo o seu morador, "estava lendo um jornal na sala de visitas de sua residência [e] nesse ínterim chegou à janela o seu vizinho de nome Luiz Batista de Sousa e perguntou o que havia de novo no jornal do dia, ao que respondeu que não havia novidade", ver Sumário Crime ${ }^{\circ}$ 228, 1944, Reinaldo Marcelino Filho, maço de 13/04 a 31/08/1944.

${ }^{26}$ Sumário Crime ${ }^{\circ}$ 03, 1930, Moisés Francisco de Melo, maço de 09/01 a $12 / 12 / 1930$
} 
Na casa e... na rua

No entanto, não era apenas nas proximidades da moradia $e$ nas portas e janelas de casa que as mulheres eram vistas na cidade. Boatos e conversas sobre traições, chifres e querelas diversas entre vizinhas e conhecidas eram parte daquele mundo, mas podiam acabar em desavenças $e$ intrigas como a que envolveu Severina Pereira, que saíra da rua Irineu Jófili e fora até a Nova Olinda acertar contas com Maria Tavares, porque esta andara falando pela cidade que Severina botava chifre no amásio. ${ }^{27}$ Em outro episódio, numa tarde de fevereiro de 1944, uma "senhora" estava indo ao centro da cidade matricular os filhos numa escola, quando de repente, em plena avenida Getúlio Vargas, uma mulher desconhecida passou a detratá-la com epítetos como "rapariga, safada, puta, escrota e catraia indecente" ${ }^{28}$ Indignada pelo escândalo e constrangimento público que lhe causaram tamanhas injúrias, contou o caso ao marido, que contratou um advogado para impetrar uma queixa crime contra a agressora. Egídia Gomes, em seu depoimento, confessou que estava meio alcoolizada no momento da agressão verbal $e$ que confundira Laura Balduino Batista com a amásia do seu marido.

Neste episódio, ocorrido em uma avenida saneada nas proximidades do centro de Campina Grande, observam-se códigos e percepções diferentes em tensão. Egídia Gomes buscara exatamente uma rua movimentada para desagravar quem pensava fosse a amásia do seu marido. Sua gritaria e palavreado teve o efeito esperado, chamando a atenção de transeuntes, dos moradores da casa em frente da qual ocorrera a agressão e das proximidades. Ela havia feito a coisa certa, pensava. Só que a vítima de sua descontrolada agressão utilizou-se exatamente da dimensão do escândalo causado para que ela fosse punida. Uma e outra aprenderam no mesmo episódio como os códigos de viver na cidade, observar e usar seus espaços, ler as fisionomias dos

${ }^{27}$ Ação Penal n 249, 1944, Severina Pereira, maço de 28/01 a 13/11/1944.

${ }^{28}$ Queixa-Crime n ${ }^{\circ} 235,1944$, Egídia Gomes, maço de 11/03 a 03/11/1944. 
Fabio Gutemberg Ramos Bezerra de Sousa

transeuntes podiam ser manipulados diferentemente. Devem ter aprendido lições diversas com o encontro daquela tarde de fevereiro.

\section{Epílogo}

As mulheres do meio popular não viviam apenas no restrito mundo do lar, como muitos queriam. Faziam incursões diversas pelas ruas da cidade, fosse em busca de uma nova morada, de alguém que procuravam caluniar, ou mesmo de uma desafeta caluniadora; passeavam e faziam compras, visitavam amigos $e$ familiares, iam à procura de políticos e compadres, pedir ajuda ou trabalho para o marido ou amásio; levavam filhos, vizinhos e amigos para o hospital ou a delegacia; visitavam as igrejas $e$ a tenda de curandeiros; iam à feira vender e comprar; eram rezadeiras respeitadas, operárias assediadas, donas de casas enclausuradas, espancadas ou difamadas. ${ }^{29}$ Elas eram encontradas nas portas das casas vizinhas, a conversar, ou na sua própria casa, a olhar o movimento da rua, observar a vida alheia ou flertar com homens que por ali passavam. Vez por outra eram espancadas por maridos ou vizinhos (neste último caso, encontramos apenas mulheres viúvas ou mães solteiras) $e$ condenadas ou admoestadas pela justiça; nesses casos, no entanto, percebe-se claramente que enfrentavam maridos $e$ amásios no braço ou desafiando-os, como fez Ana Pereira com José Cozinheiro.

Elas dominavam, de maneira própria, como mulheres num mundo fortemente masculinizado, os códigos que um certo viver na cidade implicavam. Mas viver em Campina Grande entre os anos 1930-1940 era algo cambiante e, como todos os outros

${ }^{29}$ Sobre as imagens e estigmas que existiam contra as mulheres que costumavam andar sozinhas ou acompanhadas pelas ruas da cidade, em horários considerados impróprios, ou em companhias desabonadoras, ver ESTEVES, M. Meninas perdidas... Op. cit., pp.117-202 e CAVALCANTI, S. Mulheres modernas, mulheres... Op. cit., pp.52-56. 
Na casa e... na rua

moradores do lugar, as mulheres do meio popular tiveram que aprender a lidar com os novos códigos que se lhes interpunham no dia a dia, como a proibição de criar animais soltos pelas ruas, os cuidados de si e dos filhos, a velocidade dos automóveis nas ruas calçadas, os médicos apalpando seu corpo, filhos indo à escola, aprendendo novas profissões ou virando larápios, o manuseio de máquinas nas fábricas de fiação e tecelagem, etc. Não era exatamente a vida que algumas delas tinham no lugar de origem, mas era uma vida com um forte peso das experiências trazidas, que não se perdiam do dia para a noite, apesar do ritmo dos automóveis, da dúbia claridade da luz elétrica, da beleza do cinema e dos novos ensinamentos que seus filhos tinham na rua $e$ na escola. ${ }^{30}$

Alguns estudos de gênero ou estudos sobre as mulheres costumam enfatizar os perigos e limites da circulação das mulheres pela cidade. ${ }^{31}$ Andar a certas horas da noite desacompanhada, ou em companhias duvidosas e em certos lugares poderia ser uma senha para a difamação e estigmas, para o nome "cair na boca do mundo". A bibliografia mostra o quanto os olhares da sociedade estavam atentos aos passos das mulheres e às formas como se comportavam em lugares públicos.

Naturalmente que não era só para as mulheres que o olhar de certas instituições se voltava: agricultores mal educados,

\footnotetext{
${ }^{30} \mathrm{O}$ crescimento populacional de Campina Grande, entre as décadas de 1920 e 1940, ocorrera como na maioria das grandes cidades brasileiras, pressionado mais pelo advento de pessoas e famílias da zona rural, de outros municípios do Estado e de estados vizinhos (especialmente de Pernambuco) e de alguns estrangeiros (principalmente sírio-libaneses que à época formaram uma verdadeira "colônia" na cidade) do que do crescimento vegetativo da sua população. No caso específico de Campina Grande, por ser uma cidade/entreposto comercial, atraia muitos forasteiros, ver CÂMARA, Epaminondas. Datas campinenses. João Pessoa, Departamento de Publicidade, 1947, pp.125-126 e 188 e numa perspectiva nacional, WiSSENBACH, C. Da escravidão à liberdade.... Op. cit.

${ }^{31}$ Ver Esteves, M. Meninas perdidas, Op. cit., pp.117-202 e CAvalCanTI, S. Mulheres modernas, mulheres..., Op. cit., pp.52-56.
} 
operários rebeldes, vadios, vagabundos e prostitutas eram constantemente assediados pelos estigmas e preconceitos acionados por pessoas, instituições e grupos que investiam suas cartas na institucionalização de valores burgueses, que tinham no trabalho e na propriedade os seus pilares e sustentáculos.

Mas pouco se comparava ao cotidiano de uma dona de casa, uma mulher que poderia ser a esposa ou amásia de um operário, agricultor, artesão ou desempregado. Ao invés das ruas, avenidas e estradas, o centro de suas atividades era a própria casa e o seu entorno, quase sempre localizados na periferia da cidade que, diga-se de passagem, não é a mesma para todo o período que este artigo abarca. Aparentemente, tinham naquela sociedade uma geografia mínima, ou era assim que muitos queriam que fosse. Apesar dos limites que uma certa moral tentava impor-lhes, coisas mais prementes, como a necessidade de sobreviver, as levava ao trabalho nas fábricas, ou a produção de doces e bolos caseiros para venderem nas ruas, em barracas de café na feira, o que ampliava o seu mundo e suas experiências. Mas o que se viu nos episódios anteriormente narrados mostra que não só a sobrevivência interferia na geografia das mulheres na cidade. As relações de solidariedade que mantinham com vizinhos em grande medida eram heranças da vida nas pequenas vilas, arraiais, distritos e da zona rural, onde haviam vivido até chegarem à cidade; com os rearranjos que esta possibilitava, ou impunha, ganhavam nova plasticidade nos becos e ruas dos subúrbios.

A moral $e$ o olhar vigilantes de uma sociedade com traços patriarcais, ${ }^{32}$ seus valores $e$ tradições não impediam que essas mulheres quebrassem essas amarras com atitudes ousadas, como vimos nos episódios protagonizados por Antônia, Júlia e Petronila que, com a sobrevivência garantida ou não, foram além do papel

${ }^{32}$ Ver AlbuQUerQue Junior, Durval Muniz de. Nordestino, uma invenção do falo. Uma história do gênero masculino (Nordeste - 1920-1940). Recife, Edições Catavento, 2003; nesta obra o autor interpreta as noções de família e sociedade patriarcal como construções estratégicas elaboradas pelas elites decadentes do Nordeste nas primeiras décadas do século XX. 
Na casa e... na rua

que lhes reservaram e ampliaram a cartografia da cidade para si $e$ para outras tantas. ${ }^{33}$

A tematização e discussão em torno do papel da mulher, a publicação de preceitos e predicados de uma mulher honesta e do que seria sua negação, tal qual tornou-se comum na época, inclusive no meio popular, era um forte sinal de que as mulheres, cada vez mais, ampliavam seus espaços de ação na sociedade, o que redefinia os papéis $e$ as cartografias das mulheres, das relações de gênero e da cidade. ${ }^{34}$

\footnotetext{
${ }^{33}$ Cf. Esteves, M. Meninas perdidas. Op. cit. Cavalcanti faz uma aproximação entre Michel Foucault e Michel de Certeau para desconstruir a imagem de submissas e vítimas das mulheres de Campina Grande nos anos 1930-1950, mas em vez de discutir como as mulheres não se moldavam a certos preceitos da justiça, tal qual possibilita uma leitura de Certeau, conseguiu construir uma nova e estranha prisão, marcada por uma teia inconsútil que dificilmente um ser humano poderá romper, redefinir ou alargar. CAVALCANTI, S. Mulheres modernas, mulheres... Op. cit.,

${ }^{34}$ Ver Pimentel, Cristino. Mulher, dona de casa. Voz da Borborema, $\mathrm{n}^{\circ} 04$, 25/01/1938, p.03 e RochA, Adauto. Diabo de saia. Voz da Borborema, n 51 , 20/07/1938. Na bibliografia sobre Campina Grande ver CIPRIANO, Maria do Socorro. Retratos da mulher pérfida: adultério e práticas discursivas em Campina Grande (1900-1940). Projeto de Mestrado em História, Campinas, Unicamp, 1997 e CAVALCANTI, S. Mulheres modernas, mulheres... Op. cit.; sobre Recife ver REZENDE, Antônio Paulo. (Des) encantos modernos: histórias da cidade do Recife na década de 1920. Doutorado em História, USP, 1992, pp.94-99. Por fim, sobre a incidência dessa temática nos folhetos de cordel no Norte/Nordeste, ver Albuquerque JR., Durval Muniz de. Falas de astúcias e de angústias. Mestrado em História, Campinas, Unicamp, 1988.
} 